\title{
Reflexões arqueológicas sobre a questão da aprendizagem em Paulo Freire: achados enunciativos
}

Erenildo João Carlos ${ }^{1}$

Dafiana do Socorro Soares Vicente-Carlos ${ }^{2}$

\begin{abstract}
Resumo
Este artigo registra uma análise arqueológica do discurso da aprendizagem e de seus usos no dizer pedagógico freireano, baseada nas noções de aprendizagem, de discurso e de enunciado. O texto-fonte foi o livro Professora sim, tia não: cartas a quem ousa ensinar (FREIRE, 1997). A análise encontrou um conjunto de assertivas que informam o enunciado da aprendizagem em Paulo Freire. Três séries enunciativas foram identificadas como constitutivas da tessitura discursiva da aprendizagem em Paulo Freire: o aprender como algo que se realiza naturalmente no cotidiano; o aprender como uma experiência vital de todos os seres vivos; e o aprender como uma questão conexa. Conclui-se que em Paulo Freire a aprendizagem articula a prática educativa e a formação humana como aspectos enunciativamente implicados.
\end{abstract}

Palavras-chave: Aprendizagem; Discurso; Paulo Freire.

\section{Archaeological reflections on the issue of learning in Paulo Freire: enunciative findings}

\begin{abstract}
This article records an archaeological analysis of the learning discourse and its uses in Freire's pedagogical saying, based on the notions of learning, discourse and utterance. The source text was the book Professor yes, aunt no: letters to those who dare to teach (FREIRE, 1997). The analysis found a set of statements that inform the statement of learning in Paulo Freire. Three enunciative series were identified as constitutive of the discursive fabric of learning in Paulo Freire: learning as something that occurs naturally in everyday life; learning as a vital experience for all living beings; and learning it as a related issue. In conclusion, in Paulo Freire, learning articulates educational practice and human formation as enunciatively implicated aspects.
\end{abstract}

Keywords: Learning; Speech; Paulo Freire.

\section{Introdução}

É curioso o fato de o aprender passar despercebido em nossas vidas, mesmo sendo algo tão óbvio, cotidiano e naturalizado. Entretanto, quando é problematizado, seu modo de ser e sua aparente obviedade nos surpreendem, principalmente quando constatamos que ele se caracteriza como um acontecimento fundamental da dinâmica da vida, em geral, e da existência humana, em particular.

\footnotetext{
${ }^{1}$ Universidade Federal da Paraíba - UFPB, João Pessoa/PB, erenildojc@gmail.com

${ }^{2}$ Universidade Federal da Paraíba - UFPB, João Pessoa/PB, daffyanna@gmail.com 
Considerando esse fato e, sobretudo, o pressuposto de que a aprendizagem é o objeto e o objetivo fundamental da organização do trabalho pedagógico do pedagogo, seja ele situado em um processo de formação profissional ou no exercício efetivo de sua atuação laboral, realizada em diferentes e distintos espaços sociais de aprendizagem, entendemos que nunca é demais, pelas razões expostas e outras tantas possíveis de serem colocadas, problematizar e investigar seus modos de existir, a fim sistematizá-los, difundi-los ou de produzir novos conhecimentos sobre alguma de suas interfaces com a educação, com a formação das pessoas e com a dinâmica societária vigente ou passada.

Considerando que são muitas as possibilidades de enfrentar e de tratar essa questão, sentimos a necessidade de especificar o que, de fato, interessa-nos refletir neste texto e como desejamos operar nossa análise. Nesse sentido, cabe ressaltar que nosso objetivo, precisamente, é de discutir sobre a aprendizagem como um acontecimento situado no âmbito do discurso, ou seja, como uma espécie singular de formação discursiva, constituída por séries de enunciados e complexos feixes de relações enunciativas, cujo modo peculiar de existir e de funcionar tecem as condições de possibilidade do que se diz e do que se pode dizer sobre ela.

\section{Caminho teórico-metodológico e analítico-arqueológico}

Entendemos que é importante, antes de comunicar nossos achados, informar o modus operandi analítico-arqueológico (ALCANTARA; CARLOS, 2013) que empreendemos no curso de nossa escavação, reflexão, sistematização e exposição dos dizeres freireanos sobre a questão da aprendizagem.

Primeiro, frisamos que nosso objeto de interesse - a aprendizagem nos dizeres pedagógicos freireanos - foi delimitado a partir destes três critérios básicos: a) empírica e factualmente, a aprendizagem existe com contornos singulares em seu modo de ser social e histórico; b) discursivamente, a aprendizagem pode ser entendida como uma espécie de enunciado singular situado no território da linguagem; c) pedagogicamente, a aprendizagem pode ser investigada como uma atividade sobre a qual se diz algo a respeito de seu nexo com a educação e a formação humana.

Segundo, devido às peculiaridades do nosso objeto, intencionamos analisar e explicitar a 
ordem do discurso-enunciado (CARLOS, 2017) que atravessa os significados e os sentidos do termo aprendizagem, de seus usos educativos e suas funções político-pedagógicas acionados por Paulo Freire. Para isso, recorremos à Teoria Arqueológica do Discurso - TAD, esboçada por Foucault (2008), em seu livro a Arqueologia do Saber, de onde advêm as noções arqueológicas 'formação discursiva', 'discurso' e 'enunciado, empregadas neste texto, as quais apresentamos, aqui, sucinta e sinteticamente, e de forma dispersa, ao longo do texto, vez que o propósito central não é discutir seus pormenores técnicos, mas operar metodologicamente com elas, demonstrando, assim, a potencialidade analítica que guardam.

Entenda-se, aqui, portanto, o 'discurso' como um artefato cultural situado no território da linguagem, que ocupa uma esfera particular desse lugar. Nas palavras de Foucault (2008, p.122), o 'discurso' é “[...] um conjunto de sequências de signos, enquanto enunciados, isto é, enquanto Ihes podemos atribuir modalidades particulares de existência. [...]". Como 'modalidade particular de existência', o signo aparece e funciona no nível arqueológico como um discurso-enunciado. Sob o ponto de vista arqueológico, Foucault diz que "[...] todo enunciado é portador de certa regularidade e não pode dela ser dissociado [...]" $(2008$, p.163) e esclarece que, quando identificamos "[...] uma regularidade (uma ordem, correlações, posições e funcionamentos, transformações), diremos, por convenção, que se trata de uma formação discursiva [...]" (FOUCAULT, 2008, p.43). Ao considerar que os 'enunciados' são "[...] conjuntos caracterizados por sua modalidade de existência [...]" (FOUCAULT, 2008, p.132), trabalhamos com a hipótese arqueológica de que a aprendizagem aparece no dizer freireano como uma 'formação discursiva' singular, que ele aciona, de que se apropria e utiliza de um modo próprio.

Terceiro, registramos que o livro de Freire (1997) Professora sim, tia não: cartas a quem ousa ensinar é o texto-fonte que adotamos para investigar o objeto discurso-enunciado da aprendizagem em Paulo Freire. A escolha desse autor e dessa fonte se justifica por dois motivos: primeiro, porque Paulo Freire foi um estudioso envolvido cotidianamente com o trabalho social educativo, que nos deixou significativas contribuições sobre a questão, e seus escritos poderiam servir para nos ajudar a esclarecer a especificidade do aprender. Em segundo lugar, o referido livro articula outros escritos anteriores de Freire e não contempla somente um espectro temporal relevante, que atravessa várias décadas de reflexão e produção, mas também a regularidade de um modo de problematizar e argumentar sobre a questão da aprendizagem. Por 
essas razões, entendemos que o texto-fonte de Freire, escolhido para a análise, é uma produção representativa de seu pensar-dizer-fazer que registra uma série de ideias, concepções, argumentos e práticas, que evidenciam o modo freireano de colocar, discutir e tratar a questão da aprendizagem.

Em quarto lugar, o corpus de nossa análise é constituído de um conjunto de 21 fragmentos, passagens ou argumentos, registrados na materialidade física das páginas escritas do livro, que indicam pistas, evidências e demonstrações sobre o assunto, encontradas durante a escavação do texto-fonte. Esse levantamento foi feito por meio da utilização do significante 'aprendizagem' e de seus derivados 'aprender', 'aprendendo', 'aprendiz' e 'aprendizado', que serviram de palavras-chave ou descritores para localizar os referidos achados.

Portanto, com base nesses pressupostos teórico-metodológicos, escandimos o corpus encontrado, a fim de entender e explicitar o aparecimento da questão do aprender na ordem do discurso freireano. Nesse processo, foram desenterradas várias séries enunciativas correlacionadas com a questão em tela, de que trataremos a seguir.

\section{A aprendizagem como questão}

À primeira vista, não encontramos no livro Professora sim, tia não: cartas a quem ousa ensinar uma discussão sistemática, centrada, especificamente, na questão da aprendizagem nem localizamos um capítulo em que Freire analisasse a noção da aprendizagem, sua natureza e seu papel na constituição da educação, como fez com outros assuntos em outros escritos, como, por exemplo, a noção de oprimido, de extensão, de analfabetismo, de alfabetização ou de conscientização. Entretanto, isso não significa dizer que a aprendizagem esteja ausente no referido texto-fonte e no universo de interesse de Paulo Freire. A diversa e dispersa menção feita ao assunto demonstram tanto o reconhecimento de sua importância, fundada em múltiplas razões apresentadas em suas reflexões e argumentos sobre temas conexos, quanto a regularidade de um posicionamento da aprendizagem que merece ser erigida à condição de objeto de conhecimento e de intervenção consciente.

Visando entender como a aprendizagem foi posicionada como uma questão relevante, encontramos três séries enunciativas elucidativas que podem ser apresentadas da seguinte 
maneira: a) o aprender como algo que se realiza naturalmente no cotidiano; b) o aprender como uma experiência vital de todos os seres vivos; e c) a estratégia argumentativa de tratar o aprender como uma questão conexa. Vejamos cada um desses achados, integrantes da ordem do discurso sobre a aprendizagem em Freire.

\section{0 aprender como algo que se realiza naturalmente no cotidiano}

Comecemos assinalando e analisando a série enunciativa freireana do aprender como uma atividade naturalizada no cotidiano das pessoas, em geral, que assinala a aprendizagem como um processo constituinte do pensar-dizer-fazer diário, cuja experiência afeta a todos, em todos os momentos e lugares, mas que, não obstante, nem sempre é apreendida conscientemente no movimento efetivo de nosso agir diário. Sobre isso, encontramos o seguinte registro:

Comecemos pelo contexto concreto. Pensemos em momentos importantes de um dia nosso no contexto de nossa cotidianidade. Despertamos, tornamos o banho matinal, saímos de casa para o trabalho. Cruzamos gentes conhecidas ou não. Obedecemos aos semáforos. Se estão verdes, atravessamos as ruas; se vermelhos, paramos à espera. Fazemos tudo isso sem, contudo, nos perguntar uma vez sequer porque fizemos. Nos damos conta do que fazemos, mas não indagamos das razões por que fazemos. É isso o que caracteriza o nosso movernos no mundo concreto da cotidianidade. Agimos nele com uma série de saberes que ao terem sido aprendidos ao longo de nossa sociabilidade viraram hábitos automatizados. E porque agimos assim nossa mente não funciona epistemologicamente. Nossa curiosidade não se "arma" em busca da razão de ser dos fatos (FREIRE, 1996, p.69-70, grifo nosso).

Ao refletir sobre esse fragmento, verificamos o registro da simultaneidade de vários pontos relevantes sobre a questão da aprendizagem. O primeiro diz respeito à aprendizagem como um acontecimento em conexão íntima com o agir cotidiano, isto é, como uma atividade corriqueira, tácita, naturalizada, que ocorre de modos distintos em tempos e lugares diferentes. O segundo aspecto consiste em reconhecer que o agir cotidiano sempre é orientado, conscientemente ou não, por saberes aprendidos, que, tal como as próprias ações, são automatizados e cristalizados em hábitos, razão por que não seriam pensados no exato momento em que são realizados. Freire (1997, p.69-70) assevera que é comum agirmos “[...] sem

$$
\text { Periódico Horizontes - USF - Itatiba, SP - Brasil - e020056 }
$$


nos perguntar uma vez sequer por que o fizemos. [...]", sem indagarmos "[...] as razões por que fazemos [...]". Por último, o fragmento afirma que, quando estamos imersos no cotidiano, 'nossa mente não funciona epistemologicamente, e "[...] nossa curiosidade não se "arma" em busca da razão de ser dos fatos $[\ldots] "$.

Esse achado informa algo interessante sobre a aprendizagem, ou seja, que a naturalização do aprender indica a possibilidade de se apresentar no nível da consciência de sua existência como um obstáculo epistemológico que precisa ser superado para que a aprendizagem possa ser considerada como uma questão importante.

Ora, se uma das consequências do caráter tácito, naturalizado e supostamente óbvio do fazer-aprender cotidiano das pessoas se expressa na possibilidade de não lhe conferirmos o valor que merece e, por conseguinte, deixa de problematizar a aprendizagem e de erigi-la como uma questão existencial relevante na formação humana, contraditoriamente, ao se cogitar sobre o aprender e identificá-lo como algo naturalizado, pela via da reflexão sobre a própria experiência cotidiana, é inegável o fato de que ele representa uma espécie de atividade eliminável da existência, por ser um acontecimento verificável em qualquer lugar e situações e que afeta qualquer indivíduo, grupo ou classe social de maneira espontânea ou diretiva, casual ou sistemática, com fins, justificativas e propósitos dos mais variados tipos.

Portanto, pensar no aprender epistemologicamente implica indagar sobre o que é aprender, como se aprende e o que se aprende. Desse modo, desnatura-se sua existência cotidiana ao desembutir de nossa experiência o saber prático que temos que adquirir posto em nosso fazer individual e coletivo diário.

\section{O aprender como uma experiência vital de todos os seres vivos}

Outro achado sobremaneira importante, complementar e explicativo do anterior diz respeito à série enunciativa que vincula a aprendizagem ao crescimento dos seres vivos. Esse nexo agrega a noção de aprendizagem, a existência de um conteúdo semântico mais lato, desenhado pelo significado genérico do aprender como um acontecimento inerente à vida, como se encontra anotado na seguinte passagem: 
Crescer faz parte da experiência vital. [...]. Crescer entre nós é algo mais que crescer entre as árvores ou entre os animais, que, diferentemente de nós, não podem tomar seu próprio crescimento como objeto de sua preocupação. Crescer entre nós é um processo sobre o qual podemos intervir. O ponto de decisão do crescimento humano não se acha na espécie. Nós somos seres indiscutivelmente programados mas, de modo nenhum, determinados. E somos programados sobretudo para aprender, como salienta François Jacob (1991) (FREIRE, 1996, p.83-84, grifo nosso).

Como se lê nessa passagem, Freire recorre à assertiva de que 'crescer faz parte da experiência vital'. Nesse caso, o achado relevante diz respeito ao fato de que os seres humanos seriam capazes de aprender tanto quanto qualquer ser vivo. Relacionada ao crescimento, a aprendizagem é um acontecimento próprio da vida, ou seja, um traço genérico da dinâmica da vida de todos os seres vivos, sem exceção. Esmiuçando esse achado, destacamos quatro aspetos constitutivos do discurso-enunciado do aprender-crescer.

Primeiro: a noção de aprender, como uma 'experiência vital', posiciona a aprendizagem no seio da natureza, como um acontecimento próprio da vida. Esse fato atinge todos os seres vivos, excluindo, evidentemente, a matéria inanimada, as coisas propriamente ditas, pois elas não aprendem nem crescem. Em certa medida, ao se conceber o crescer como um modo genérico de aprender, diz-se que a semântica ampliada do aprender, como uma 'experiência vital', afirma o crescer-aprender como algo necessário à continuidade da vida, como uma espécie de dispositivo natural que viabiliza a reprodução da espécie e a sobrevivência de cada ser vivo singular no ambiente em que vive. Sem o aprender-crescer contínuo da espécie e do ser vivo singular, a vida e a existência seriam postas em risco. Portanto, o aprender-crescer é um requisito vital, cuja falta ou precariedade dificultaria a reprodução da vida.

Segundo: ao reconhecer o aprender como uma experiência vital, a noção de aprendizagem não se limitaria a descrever o aprender como uma atividade restrita, circunscrita e exclusiva da existência humana, vez que, genericamente, todos os seres vivos aprendem. Nessa perspectiva, a 'experiência vital' de crescer desantropologiza o aprender, porque, qualificada dessa maneira, a aprendizagem não seria um acontecimento exclusivamente humano, já que, assim como o ser humano, qualquer ser vivo aprende.

Em outras palavras, se a aprendizagem se encontra inscrita como uma dimensão da natureza, uma espécie de propriedade constitutiva da matéria vida ou se é, necessariamente, 
uma experiência vital - imprescindível constitutiva e ineliminável da vida de qualquer espécie, um traço ontológico da vida em si - não seria apropriado dizer que ela é um acontecimento específico do gênero humano, cuja singularidade poderia servir como um critério para identificar o modo de existir exclusivo da vida humana.

Por ser vital, a aprendizagem não pode ser eliminada da vida humana e, ao mesmo tempo, não particulariza nem diferencia, por si mesma, a condição humana do modo de viver das outras espécies. Nesse sentido, o aprender-crescer não seria um acontecimento antropológico propriamente dito, já que é um aspecto ontológico da vida em geral, isto é, um pressuposto natural imprescindível à reprodução da vida e à preservação da espécie, seja ela qual for.

Terceiro: a enunciabilidade da inerência e a ineliminabilidade da experiência vital do aprender, como constituinte da existência humana, significam que o aprender é uma atividade onipresente e difusa, que afeta a todos em todos os lugares e tempos. Conscientemente ou não, intencionalmente ou não, deliberadamente ou não, sistematicamente ou não, formalmente ou não, o ser humano sempre se encontra na condição de sujeito que aprende. Assim, ninguém escaparia da aprendizagem, pois ela se efetiva em todo tempo e lugar, em qualquer situação ou circunstância. Dito de outro modo, todo espaço-tempo sociocultural existente concretizar-se-ia como uma oportunidade de a aprendizagem acontecer. Isso explicaria sua presença ineliminável no cotidiano.

Quarto: a série enunciativa de que o ser humano não experimenta o processo de aprender-crescer do mesmo modo como fazem os outros seres vivos, como as árvores e os animais, informa que o crescer-aprender humano não seria determinado a priori pelas leis da natureza. Ou seja, diferentemente dos demais seres vivos, o ser humano pode erigir seu crescimento como objeto de sua preocupação, seja no âmbito da singularidade da individualidade de cada pessoa, seja no complexo de relações sociais específicas instauradas com o fim de socializar os membros da coletividade no universo cultural que constitui determinados agrupamentos humanos (grupos sociais, famílias, instituições religiosas, escolas, empresas, partidos, ONGS, movimentos sociais, por exemplo).

Considerando o que foi exposto, pode-se dizer que, assim como no ambiente natural o crescer-aprender é uma atividade necessária à reprodução da vida de animais e de plantas, 
também é um pressuposto do complexo desenvolvimento cotidiano e histórico da existência cultural e social de mulheres e de homens, de crianças, adolescentes e jovens, de adultos e idosos situados no mundo.

\section{O aprender como uma questão conexa}

Outro achado relevante sobre a aprendizagem, em Freire, diz respeito ao dispositivo argumentativo que ele empregava para problematizar a aprendizagem e conferir-Ihe visibilidade, reconhecimento e importância. Referimo-nos, aqui, ao argumento associativo que liga a aprendizagem a outra coisa diferente dela, ou, ainda, que a situa estrategicamente no contexto de alguma relação existente, posicionando-a como um objeto intrínseco, constitutivo da coisa relacionada. Vejamos o exemplo da relação entre o educador e o educando, ressaltada na passagem abaixo:

Passo a me centrar na análise das relações entre educadora e educandos. Elas incluem a questão do ensino, da aprendizagem, do processo de conhecerensinar-aprender, da autoridade, da liberdade, da leitura, da escrita, das virtudes da educadora, da identidade cultural dos educandos e do respeito devido a ela. Todas essas questões se acham envolvidas nas relações educadoraeducandos (FREIRE, 1997, p.51, grifo nosso).

Esse registro demonstra a regularidade do uso estratégico da relação como um dispositivo de reflexão e de problematização. Arqueologicamente falando, esse fragmento informa a presença de uma formação discursiva que se caracteriza por conceber a ideia de que a aprendizagem é uma atividade 'anterior e concomitante' realizada por 'quem ensina', que é necessária ao 'aprendiz, que se prepara para ensinar' (o aprender do ensinante/docente/professor/educador) ou, ainda, da 'aprendizagem de quem, criança ainda, está no começo de sua escolarização' (o aprender do estudante/aluno/aprendiz/educando).

Sabe-se que, embora o ato de relacionar ' $a$ ' $a$ ' $b$ ' ou de inserir, situar e localizar ' $a$ ' num contexto onde existe uma relação entre ' $b$ ' e ' $c$ ' seja um achado precioso, esclarecedor e pertinente encontrado em nossa escavação, a respeito de distintas maneiras de abordar argumentativamente o assunto, de diferentes modos de conferir visibilidade, reconhecimento e 
importância investigativa, educativa e pedagógica a determinado acontecimento, isso não significa que essa estratégia argumentativa seja suficiente, em si mesma, para entendermos a singularidade da questão em tela. Como se diz, ela é, sem dúvida, necessária, mas não suficiente para explicitar de uma só vez a questão da aprendizagem em Freire.

Ao escandir o enunciado da aprendizagem como uma questão conexa, examinando outras passagens do texto-fonte de Freire (1997) encontramos um feixe de relações enunciativas que conectam a aprendizagem com a formação humana e a prática educativa. Objetivando discutir sobre esses possíveis nexos, localizamos vários achados que apontam diversas séries enunciativas que orientam sobre a questão da aprendizagem como implicada em variados temas e correlacionada com práticas educativas e diversos lugares sociais de aprendizagem, como, por exemplo, ao ato de estudar e à identidade cultural, como demonstra esta passagem, em que Freire escreveu o seguinte:

Comecemos por estudar, que envolvendo o ensinar do ensinante, envolve também de um lado, a aprendizagem anterior e concomitante de quem ensina e a aprendizagem do aprendiz que se prepara para ensinar amanhã ou refaz seu saber para melhor ensinar hoje, ou, de outro lado, aprendizagem de quem, criança ainda, se acha nos começos de sua escolarização (FREIRE, 1997, p.20, grifo nosso).

Esse fragmento denota a relevância conferida à questão da aprendizagem em meio à discussão sobre a prática docente, cuja atividade competente e consequente pressupõe um professor - 'ensinante' - que aprenda antes o que objetiva ensinar - e um aluno - aprendiz - que se aproprie efetivamente do que o professor ensina. Em última instância, o argumento apresentado erige a aprendizagem como o objeto visado da prática educativa escolar, cujo fim orientaria, necessariamente, o pensar-fazer educativo do ensinante e do aprendiz no curso do processo de escolarização.

Em outras palavras, a passagem supracitada contempla, pelos menos, duas séries enunciativas constitutivas da formação discursiva da aprendizagem. A primeira se refere ao reconhecimento da aprendizagem como um aspecto intrínseco à prática educativa do espaço social escolar. Nesse caso, Freire assinala a aprendizagem acontecendo antes mesmo de o trabalho educativo docente se efetivar. Nela, o aprender acontece no momento da 
profissionalização docente, cuja formação requer que o 'ensinante' aprenda a ensinar, qualificando-se teórica e metodologicamente para seu exercício competente, e antes de se encontrar em situações concretas de ensino, vez que necessita demonstrar o que aprendeu sobre como organizar previamente a forma e o conteúdo que ensinara, selecionando as melhores maneiras de fazê-lo.

Portanto, concebida a partir do princípio da anterioridade, cuja relevância confere legitimidade ao exercício autorizado da docência, como profissional, a aprendizagem adquire o status de regra pedagógica, uma espécie de imperativo pedagógico que deve orientar a organização do trabalho educativo escolar. Tal como já tratamos, assim como seria impossível para qualquer pessoa escapar da experiência de aprender, também seria impossível ser docente sem aprender antes, durante e depois do pensar-dizer-fazer docente realizado.

A segunda série enunciativa que aparece na citada passagem reforça o reconhecimento da aprendizagem como regra de ouro responsável pelo funcionamento de todo o processo escolar. Ou seja, em cada fase e etapa da escolarização, em cada disciplina e conteúdo ensinado, em cada espaço e situação pedagógica da escola, algo deve ser aprendido intencional e sistematicamente. Estritamente falando, o aprender escolar não se caracteriza pelo acaso, pelo espontaneísmo docente nem pelo automatismo do cotidiano. No contexto escolar, 'ensinantes' e 'aprendizes' precisam ser 'corpos conscientes'.

Posta dessa maneira, a aprendizagem exige do educador e de outros profissionais da escola uma série de decisões para organizar o processo educativo escolar, de modo que ela seja efetivamente exitosa em seus propósitos. Nesse cenário, aparecem o reconhecimento, a valorização e a escuta das vivências, das trajetórias de vida individuais, familiares, geracionais, regionais, étnico-raciais, de gênero e de classe dos/das aprendizes, conforme indica o fragmento abaixo:

Perguntar-nos em torno das relações entre a identidade cultural, que tem sempre um corte de classe social, dos sujeitos da educação e a prática educativa é algo que se nos impõe. É que a identidade dos sujeitos tem que ver com as questões fundamentais de currículo, tanto o oculto quanto o explícito $e$, obviamente, com questões de ensino e aprendizagem (FREIRE, 1997, p.63, grifo nosso). 
Convém enfatizar que, embora “[...] perguntar-nos em torno das relações entre identidade cultural [...] e a prática educativa [...]" (FREIRE, 1997, p.63) confira ao aprender o status de algo relevante no processo formativo das pessoas, o que desencadeia a necessidade de que essas vinculações sejam problematizadas e conhecidas, como "[...] questões de ensino e aprendizagem [...]" (FREIRE, 1997, p.63), não devemos pensar, conforme já refletimos em outro lugar deste texto, que isso é suficiente para entendermos a especificidade dos constituintes enunciativos da aprendizagem como um acontecimento particular.

Ao tratar argumentativamente a aprendizagem desse modo, conectando-a com alguma interface da escolarização, como formação docente, ensino, temas sociais, estudo, fases e etapas da escolarização, Freire contribuiu para o reconhecimento do status e do papel da aprendizagem na formação humana, demonstrando o nexo ontológico entre aprendizagem, formação humana e prática educativa, como, por exemplo, a que ocorre no contexto escolar. Aprofundemos essa conexão.

\section{Nexos entre a aprendizagem, a formação das pessoas e a prática educativa}

Conforme temos analisado ao longo deste texto, constatamos que a naturalização do cotidiano possibilita o estabelecimento de uma relação existencial com a aprendizagem, que tende a nos levar a apreendê-la como um acontecimento sem importância, a ponto de passarmos por ela despercebidamente. Por outro lado, o encontro do nexo entre aprendizagem, formação humana e prática educativa escolar é um achado importante para se reconhecer a aprendizagem como uma atividade imprescindível na dinâmica da existência humana, da formação das pessoas e da prática educativa em particular.

Nesta seção, aprofundaremos essa relação, ao problematizar o enunciado da aprendizagem como objeto de sua curiosidade epistemológica, conectada intrinsecamente com a formação das pessoas em geral, mais precisamente, com práticas sociais que se encontram envolvidas com processos formativos genuinamente educativos, ou seja, orientados pela intenção de criar situações intersubjetivas em que se almeje conscientemente aprender algo, previamente decidido e organizado. Com esse intuito, trazemos à baila o seguinte fragmento, em que Freire afirma: 
A questão central que se coloca a nós, educadoras e educadores, no capítulo de nossa formação permanente, é como, do contexto teórico, tomando distância de nossa prática, desembutimos dela o saber dela. A ciência que a funda. Em outras palavras, é como do contexto teórico "tornamos distância" de nossa prática e nos tornamos epistemologicamente curiosos para então apreendê-la na sua razão de ser (FREIRE, 1997, p.70, grifo nosso).

Pôr-se epistemologicamente em relação à aprendizagem, problematizando-a para conhecer sua particularidade, sua especificidade e suas possíveis funções no processo de desenvolvimento sócio-histórico, no curso do desenvolvimento da sociabilidade das pessoas, é uma evidência registrada no conteúdo desse e de outros fragmentos que constituem o corpus analisado neste texto.

Ao considerar essa série enunciativa, tendo em vista o saber acionado na rede argumentativa freireana, verifica-se que os seres humanos tendem a fazer do próprio cresceraprender 'objeto de sua preocupação' e intervenção e a tratá-lo como uma atividade que tem contornos particulares, realizada de maneira intencional, deliberada e sistematizada nos processos formativos das pessoas.

Nesse sentido, ao posicionar a aprendizagem como um fim consciente a ser almejado, resultante de processos sociais deliberados, como o agir educativo escolar, por exemplo, Freire defende veementemente que educadores e educadoras devem fazer da aprendizagem uma das questões centrais de sua curiosidade e sugere que eles tomem distância de sua prática e se ponham epistemologicamente diante dela, a fim de apreender sua razão de ser, de 'desembutir o saber' que ela contempla e de entender a 'ciência que a funda'.

No ínterim dessa argumentação, encontra-se o imperativo do enunciado da aprendizagem como um objeto cognoscível. Esse enunciado erige o aprender como algo merecedor de conhecimento, seja no que diz respeito a 'o que' e 'como' se aprende e a 'o que ela é' propriamente.

Em certa medida, esse achado, que traz à luz a cognoscitividade do aprender, evidenciando-a como um elemento constituinte da enunciabilidade da ordem discursiva freireana sobre a aprendizagem, ressalta-a como um objeto que exige ser investigado, analisado, conhecido e apropriado e como um objeto singular, com contornos existenciais peculiares e usos singulares no seio do pensar-dizer-fazer pedagógico-educativo freireano. 
Ao puxar os fios epistemológicos da dinâmica da vida dos seres vivos, em geral, e da existência e da cotidianidade dos seres humanos, em particular, notamos que um dos aspectos evidentes do aprender-crescer, como experiência vital e existencial, não só se expressa como uma espécie de atividade inerente à vida, como também dependente da atividade realizada por quem vivencia determinada experiência de aprendizagem.

Nessa perspectiva, o fazer desponta como uma condição necessária para se aprender, pois só se aprende fazendo. Como diria Freire (p.73), “[...] assim como é preciso falar para falar, é preciso escrever para escrever. Ninguém escreve se não escreve, assim como ninguém aprende a andar se não andar. [...]". Em outros termos, podemos, conforme já analisado, agir epistemologicamente', aprender a aprender e intervir conscientemente sobre o nosso próprio aprender-crescer ao longo da vida.

Ao dispor o aprender como resultado do fazer, do agir individual ou coletivo, o enunciado da aprendizagem aparece caracterizado por um duplo reconhecimento, a saber: o da valorização do sujeito como um aspecto fundante da razão de ser da natureza da aprendizagem; e o do agir intencional, tendo em vista efetivar alguma aprendizagem específica, decidida previamente, o qual deve ser orientado conscientemente pela série de saberes correlacionados com que o fundamenta. Como afirmara Freire (1997, p.70), é:

[...] desvelando o que fazemos desta ou daquela forma, à luz de conhecimento que a ciência e a filosofia oferecem hoje, que nos corrigimos e nos aperfeiçoamos. É a isso que chamo pensar a prática e é pensando a prática que aprendo a pensar e a praticar melhor [...].

Como se pode ler nesse trecho, o enunciado da cognoscitividade do aprender informa que a prática da aprendizagem pode ser consciente, fundamentada e crítica. Ou seja, quando pensamos nela, aprendemos a pensá-la e a praticá-la melhor. Esse posicionamento da aprendizagem é um acontecimento discursivo consubstanciado nas séries de signos que aparecem nas passagens citadas e no fragmento abaixo, em que Freire nos fala sobre a inserção consciente e atuante do ser humano no mundo, de modo que ao tempo em que busca saber sobre seu estar sendo no mundo, como sujeito que aprende, por forca das circunstancias e das ocasiões, também procure, deseje e assume o aprender a aprender como telos de seu 
desenvolvimento e de sua formação, de seu ser mais, vez que é próprio dos seres humanos serem 'programados para aprender'. Ciente dessa perspectiva, Freire assevera que é

[...] preciso que o nosso corpo, que socialmente vai se tornando atuante, consciente, falante, leitor e "escritor", se aproprie criticamente de sua forma de vir sendo que faz parte de sua natureza, histórica e socialmente constituindose. Quer dizer, é necessário que não apenas nos demos conta de como estamos sendo, mas nos assumamos plenamente, como estes "seres programados para aprender" [...]. É necessário então que aprendamos a aprender, vale dizer, que entre outras coisas, demos à linguagem oral e escrita, a seu uso, a importância que the vem sendo cientificamente reconhecida (FREIRE, 1997, p.25, grifo nosso).

Convém, no entanto, enfatizar que, embora Freire reconheça a cognoscitividade do aprender-crescer como o elemento central da questão educativa, não devemos concluir que a cognoscitividade da aprendizagem se caracterize unicamente pela inserção racional do ser humano no cotidiano, na sociedade ou na história, por meio de uma mente 'armada epistemologicamente'. Quando Freire se refere à consciência do ser humano, não a concebe tão somente como algo localizado na cabeça, no cogito, mas também na completude do corpo humano, por meio do qual o indivíduo concreto se insere no mundo, apropria-se dele e se constitui nele. Descrevendo a consciência desse modo, a humanização do indivíduo passaria por processo no qual deveria assumir sua posição de sujeito que aprende conscientemente, ou seja, que aprende a aprender por meio de seu corpo consciente, conforme pode ser lido na seguinte passagem:

É preciso que a escola progressista, democrática, alegre, capaz, repense toda essa questão das relações entre corpo consciente e mundo. Que reveja a questão da compreensão do mundo, enquanto produzindo-se historicamente no mundo mesmo e também sendo produzida pelos corpos conscientes em suas interações com ele. Creio que desta compreensão resultará uma nova maneira de entender o que é ensinar, o que é aprender, o que é conhecer de que Vygotsky não pode estar ausente (FREIRE, 1997, p.49-50, grifo nosso).

O anúncio do apreender no e com o mundo e do aprender a aprender de cada indivíduo ao longo da vida, expresso na noção de 'corpo consciente', consubstancia o modo cognoscível de estar no mundo, de existir nele e com ele e de aprender. A noção de 'corpo consciente' se 
distancia da concepção de uma coisa qualquer, de uma espécie de corpo-coisa inerte e passivo no mundo, sem consciência do espaço-tempo social, histórico e cultural em que se encontra e de um corpo vivo imerso na natureza, indiferente a ela, simplesmente ajustado e adaptado às circunstancialidades do ambiente. Um tipo de ser vivo que não intervém na natureza, plenamente assujeitado aos ditames de seu determinismo ou de uma simples consciência sem corpo, como as almas, os espíritos e as coisas mágicas do gênero, por exemplo. Ao contrário da semântica do corpo-coisa e do ser vivo determinado, a noção freireana de 'corpo consciente' codifica uma relação existencial, epistemologicamente orientada para intervir conscientemente no mundo, em sua relação com ele, e sobre si mesmo.

A cognoscitividade da aprendizagem, também expressa na noção de 'corpo consciente', desdobra-se de outras maneiras e assume outros modos de existir, como, por exemplo, a concepção do educador e do educando como sujeitos cognoscentes e da coisa aprendida como objeto cognoscível, identificando a aprendizagem como uma atividade a ser realizada de forma consciente, seja pelo educando, seja pelo educador, sobre o aprender e o aprendido, conforme se lê na seguinte passagem:

Só na medida em que o educando se torne sujeito cognoscente e se assume como tal, tanto quanto sujeito cognoscente é também o professor, é possível ao educando tornar-se sujeito produtor da significação ou do conhecimento do objeto. É neste movimento dialético que ensinar e aprender vão se tornado conhecer e reconhecer. $O$ educando vai conhecendo o ainda não conhecido e o educador, reconhecendo o antes sabido (FREIRE, 1997, p.79, grifo nosso).

Apresentar a enunciabilidade da aprendizagem precisamente como uma atividade cognitiva, em que o processo de aprender seja consciente e inteligível, centrado no primado epistêmico de compreender o que se aprende, significa contrapor-se ao aprender tácito, corriqueiro e automático, próprio do agir-fazer cotidiano. Esses mecanismos, típicos do agir cotidiano, marcados pelo automatismo operante do estímulo e resposta, fazem dos humanos seres quase-coisa, ao retirar deles sua condição ontológica de ser-sujeito, de ser corpoconsciente.

Constatamos que o fazer-aprender mecânico, realizado pelo educador ou pelo educando, aparece nos escritos freireanos como uma característica típica do automatismo do cotidiano, 
que, de certo modo, é incorporado como parâmetro das práticas e dos processos educativos autoritários, manipulatórios e bancários, que tendem a priorizar a transmissão do saber, como estratégia dominante do saber-fazer docente, 'armada' de uma didática impositiva, mnemônica, mágica e tautológica, e a valorizar a passividade do aprendiz acomodado, receptivo e acrítico em relação ao que aprende, ao mundo e à sua história de vida, conforme anotam várias passagens do texto-fonte em apreço, como a seguinte, em que Freire escreve:

[...] uma escola que, continuando a ser um tempo-espaço de produção de conhecimento em que se ensina e em que se aprende, compreende, contudo, ensinar e aprender de forma diferente. Em que ensinar já não pode ser este esforço de transmissão do chamado saber acumulado, que faz uma geração à outra, e aprender não é a pura recepção do objeto ou do conteúdo transferido. Pelo contrário, girando em torno da compreensão do mundo, dos objetos, da criação, ela boniteza, da exatidão científica, do senso comum, ensinar $e$ aprender giram também em torno da produção daquela compreensão, tão social quanto a produção da linguagem, que é também conhecimento (FREIRE, 1997, p.05, grifo nosso).

Notamos, mais uma vez, o caráter cognoscível do aprender, cujo aparecimento seria mais apropriado seria na escola, pelo menos por duas razões já tratadas neste texto: a) o aprender ocorreria ao longo de todo o processo de escolarização, afetando não somente o aprendiz, como também o ensinante antes do processo de ensino-aprendizagem e durante; b) na escola, os sujeitos, ensinante e aprendiz, vivenciariam obrigatoriamente a experiência de aprender: um, aprendendo a ensinar; o outro, aprendendo o que se ensina.

O professor deve ensinar. É, preciso fazê-la. Só que ensinar não é transmitir conhecimento. Para que o ato de ensinar se constitua como tal, é preciso que o ato de aprender seja precedido do, ou concomitante ao, ato de apreender o conteúdo ou o objeto cognoscível, com que o educando se torna produtor também do conhecimento que the foi ensinado (FREIRE, 1997, p.79, grifo nosso).

Assim, ao conceber o ensinante e o aprendiz como corpos conscientes, que ocupam ativamente o espaço escolar, verifica-se que o enunciado da cognoscitividade do aprender a aprender aponta um fazer consciente, que busca, deliberada e sistematicamente, um conjunto de estratégias educativas possíveis e disponíveis, capazes de organizar as condições de 
aprendizagem de maneira inteligente, diversificada, consequente e significativa. Exemplo disso seria considerar o que se aprende na escola em estrita ligação com o que se aprendeu e se aprende fora dela, conforme assevera Freire:

[...] quanto mais penso e atuo assim, mais me convenço, por exemplo, de que é impossivel ensinarmos conteúdo sem saber como pensam os alunos no seu contexto real, na sua cotidianeidade. Sem saber o que eles sabem independentemente da escola para que os ajudemos a saber melhor o que já sabem, de um lado e, de outro, para, a partir daí, ensinar-lhes o que ainda não sabem (FREIRE, 1997, p.70, grifo nosso).

Utilizar a noção de aprendizagem como dispositivo que potencializa a prática de problematizar, discutir, refletir e analisar contextualizadamente o processo formativo das pessoas desenterra outro achado de suma importância sobre a aprendizagem. Em certa medida, uma implicação disso se encontra na valorização e na incorporação curricular do saber das experiências, das práticas culturais, da visão de mundo, da linguagem, da religiosidade e das condições de existência locais, regionais, nacionais e internacionais do educando. Por isso, indaga Freire (1997, p.74):

[...] De que forma entender as dificuldades durante o processo de alfabetização de alunos sem saber o que se passa em sua experiência em casa, bem como em que extensão é ou vem sendo escassa a convivência com palavras escritas em seu contexto sócio-cultural?

Não há dúvida de que essa pergunta, fundada na cognoscitividade do princípio da contextualização, gera inúmeras reflexões pedagógicas. Uma seria a de investigar o uso estratégico de recursos didático-pedagógicos como auxiliadores inteligentes, críticos e eficientes na prática de ensinar e de aprender. Como exemplo, podemos citar o uso criativo de diferentes tipos de codificação, entre elas, as codificações escritas (palavras e textos) e visuais (desenhos, fotografias), como artefatos culturais representativos da realidade do educando; o diálogo como dispositivo mediador da relação gnosiológica estabelecida entre o educando e o educador, tendo em vista compreender criticamente o que está sendo aprendido; e a pratica de ensinar-aprender articulada e comprometida com a resolução de problemas sociais efetivos, cotidianos e históricos. 
Quanto ao uso estratégico de codificações escritas e visuais, como uma espécie de artefato cultural, que exercem uma função didático-pedagógica (CARLOS, 2018), observa-se que o discurso freireano se refere a ele como um dispositivo pertinente, adequado e eficiente para os propósitos educativos, próprios do ensino e da aprendizagem. Assim, pode-se dizer que a enunciabilidade da relação entre codificação, representação e realidade com a aprendizagem assinala uma série enunciativa constitutiva do pensar-dizer-fazer freireano, recorrentemente encontrado quando trata, por exemplo, da questão da alfabetização e da formação do educador popular, como ilustra esta passagem:

[...] Assim, a ideia básica, aceita e posta em prática, é de que os jovens que se preparariam para a tarefa de educadoras e educadores populares deveriam coordenar a discussão em torno de codificações num círculo de cultura com 25 participantes. Os participantes do círculo de cultura estavam cientes de que se tratava de um trabalho de formação de educadores. (FREIRE, 1997, p.22.).

No que diz respeito ao uso na formação de educadores populares comprometidos em fazer alguma tarefa educativa com o povo, as codificações foram empregadas pedagogicamente em várias situações de aprendizagem da escrita, como em práticas de alfabetização, em que as pessoas analfabetas aprendiam a aprender a exercer seu direito de aprender a ler e a escrever a palavra e o mundo, como registra o fragmento abaixo sobre o uso da codificação em um círculo de cultura nordestino, em que se discutia sobre a noção de cultura:

Certa vez, uma alfabetizanda nordestina discutia, em seu círculo de cultura, sobre uma codificação que representava um homem que, trabalhando o barro, criava com as mãos um jarro. Discutia-se, através da 'leitura' de uma série de codificações que, no fundo, são representações da realidade concreta, o que é cultura (FREIRE, 1997, p.21, grifo nosso).

Como registram esses dois últimos fragmentos, independentemente do caso de seu emprego, as codificações escritas (palavras e textos) e visuais (desenhos, fotografias) funcionavam estrategicamente como um ponto de ligação pedagógica entre o espaço social de aprendizagem (escola ou círculo de cultura, por exemplo) e a experiência existencial de pessoas aprendizes e como um ponto de articulação do diálogo reflexivo e crítico entre o educador e o educando, que se relacionavam gnosiologicamente com o intuito de ensinar e de aprender algo. 
As duas menções feitas nos fragmentos anteriores apontam o emprego das codificações escritas e visuais associadas ao dialógico. Argumentativamente, uma coisa se liga com a outra como faces e interfaces de um modo singular de se discutir sobre a aprendizagem e de realizá-la efetivamente. Dizendo de outra maneira, na ordem discursiva freireana, a questão das codificações institui um vínculo entre o aprender dos corpos conscientes por intermédio do princípio educativo da dialogicidade, representadas por meio das codificações sobre assuntos diversos.

Ressalte-se, entretanto, que, não obstante a relevância desse feixe enunciativo de relação didático-pedagógica, constituinte da ordem geral do discurso sobre o aprender em Freire, o diálogo aparece com um status pedagógico próprio, com especificidade e funções peculiares no jogo da enunciabilidade da cognoscitividade pedagógica freireana, ou seja, como uma espécie de racionalidade necessária, que funciona, de certo modo, “[...] como selo da relação gnosiológica, e não, como pura cortesia" (FREIRE, 1997, p, 6). Por isso, esclarece Freire, que o diálogo não deveria ocorrer somente "[...] em torno dos conteúdos a serem ensinados, mas sobre a vida mesma, se verdadeiro, não somente é válido do ponto de vista do ato de ensinar, mas formador também de um clima aberto e livre no ambiente de sua classe" (FREIRE, 1997, p.59).

Certamente, o anúncio da contextualização, como princípio pedagógico, correlacionado à cognoscibilidade da prática educativa freireana, ao conceber o aprender como necessariamente significativo, crítico e libertador, requer que o que se aprende esteja em profunda conexão com o contexto do aprendiz. Os referidos casos de práticas educativas voltadas para a formação do educador popular e para a aprendizagem crítica da leitura e da escrita da palavra e do mundo aparecem como exemplos emblemáticos de aprendizagens, profundamente ligadas aos comprometimentos freireanos com a transformação social e a humanização dos seres humanos.

Assim, ao articular a aprendizagem, a formação humana e a prática social educativa com a luta pela transformação social e pela humanização das pessoas, Freire desenvolveu, defendeu e promoveu um modo de pensar-dizer-fazer pedagógico que fundamentava e orientava, por exemplo, a prática educativa de adultos em, pelo menos, duas direções: uma, como coadjuvante para enfrentar e superar os problemas cotidianos e históricos do povo latino-americano, como, 
por exemplo, o analfabetismo, e outra, engajada com a formação crítica e libertadora das pessoas, como os educandos jovens, adultos e idosos analfabetos. Especificamente sobre o analfabetismo, Freire argumenta:

[...] Mesmo que não zere as milenar e socialmente criadas relações entre linguagem, pensamento e realidade, $o$ analfabetismo as mutila e se constitui num obstáculo à assunção plena da cidadania. E as mutila porque, nas culturas letradas, interdita analfabetos e analfabetas de completar o ciclo das relações entre linguagem, pensamento e realidade, ao fechar a porta, nestas relações, ao lado necessário da linguagem escrita. [...] (FREIRE, 1997, p.07, grifo nosso).

Argumentos idênticos ou similares a esse concebem e denunciam o analfabetismo como um fenômeno social e cultural que 'mutila' e interdita 'a assunção plena da cidadania', porque, nas "[...] culturas letradas, sem ler e sem escrever, não se pode estudar, buscar conhecer, apreender a substantividade do objeto, reconhecer criticamente a razão de ser do objeto [...]." (FREIRE, 1997, p.25).

Assim, pode-se dizer que a cognoscitividade do princípio da contextualização, que interliga pensamento, linguagem e mundo, funciona como um dispositivo de crítica que se expressa em um dizer político contundente, assumidamente comprometido com a denúncia da precariedade das condições de existir dos seres humanos, social e historicamente situados, e com o anúncio da luta para melhorar a vida das pessoas dominadas, oprimidas e exploradas. Portanto, definindo-se por meio da conexão entre a formação das pessoas e os processos sociais de emancipação e humanização, o enunciado da politicidade do aprender é mais um achado encontrado nos escritos freireanos que constitui a especificidade da ordem do seu discurso pedagógico sobre a aprendizagem.

\section{Considerações finais}

Considerando o exposto, pode-se dizer que o enunciado da aprendizagem, que atravessa a rede argumentativa freireana, informa que, na vida de todo ser vivo e na existência cotidiana de todo ser humano, a aprendizagem se põe efetivamente como uma atividade natural, como um acontecimento aparentemente tão óbvio que nem sempre nos interessamos em refletir 
sobre ela. Com efeito, pode-se dizer que a aparente obviedade do aprender não aciona, por si mesma, o ato de problematizá-la como uma questão relevante.

Esse aspecto primário, provavelmente, seria uma razão da suposta obviedade que o cotidiano sugere sobre a aprendizagem, um efeito naturalizado pelo fato ontológico de ela ser constituinte e constitutiva da existência humana, por isso, onipresente. Em outras palavras: todos, em todo tempo e lugar, estariam, de algum modo, agindo e aprendendo, aprendendo e agindo, espontânea ou sistematicamente, conforme exemplifica Freire sobre o caso do aprender a falar falando.

\begin{abstract}
Ninguém rigorosamente ensina ninguém a falar. A gente aprende no mundo, na casa da gente, na sociedade, na rua, no bairro, na escola. A fala, a linguagem da gente, é uma aquisição. A gente adquire a fala socialmente. A fala vem muito antes da escrita, assim como uma certa "escrita" ou o anúncio dela vem muito antes do que a gente chama escrita. E assim como é preciso falar para falar, é preciso escrever para escrever. Ninguém escreve se não escreve, assim como ninguém aprende a andar se não andar (FREIRE, 1997, p.73, grifo nosso).
\end{abstract}

Embora certos fragmentos trazidos à baila informem que o cotidiano não "arma" nossa mente epistemologicamente para lidar com os acontecimentos que nos afetam e nos constituem diariamente, também apontam que, diferentemente dos outros seres vivos, o ser humano ocupa-se de seu cresceraprender, de indagar sobre ele, de problematizá-lo e de entender sua 'razão de ser', a fim de intervir nele de maneira mais consequente e eficiente. $O$ tipo e o modo de crescimento especificamente humano não seriam inevitáveis, impostos pelo determinismo das leis e da herança natural, mas "[...] um processo em que podemos intervir [...]", e em vez de sermos determinados naturalmente, "[...] somos seres indiscutivelmente programados $[\ldots]$ ", “[...], sobretudo, para aprender $[\ldots]$ " e, por isso, identificados como "[...] animais permanentemente inscritos num processo de aprender e buscar [...]" (FREIRE, 1996, p.63). Sobre isso, encontramos a seguinte anotação:

[...] E é exatamente porque nos foi possível, com a invenção da existência-algo mais que a vida mesma e que nós criamos com os materiais que a vida nos ofereceu - deslocar da espécie para nós o ponto de decisão de muito do que estamos e estaremos sendo. Mais ainda, porque, com a invenção social da linguagem, lado a lado com a operação sobre o mundo, alongamos o mundo natural, que não fizemos, em mundo cultural e histórico, produtos nossos, que nos tornamos animais permanentemente inscritos num processo de aprender $e$ buscar [...] (FREIRE, 1997, p.63, grifo nosso). 
Verifica-se, portanto, nesses registros, que, no caso específico do ser humano, o diferencial se encontra no fato de que ele não só vive, como acontece com os demais seres, nem só tem a capacidade de se ajustar e de se adaptar ao ambiente natural, como também produz algo novo e inventa a existência, a linguagem, os instrumentos e as estratégias para agir na natureza, transformando-a e produzindo cultura, modos sociais distintos de viver histórias variadas.

Assim, embora a vida e a existência se relacionem, retroalimentem-se e constituam a dinâmica própria de o ser humano se pôr no mundo, de aprender e de buscar, elas são elementos da realidade que exercem papéis distintos no processo de humanização do ser humano, ou seja, no curso da formação social e histórica da humanidade do homem, conforme assinala este fragmento:

\footnotetext{
Um dado importante, como ponto de partida para a compreensão crítica do crescer entre nós, existentes, é que, "programados para aprender", vivemos ou experimentamos ou nos achamos abertos a experimentar a relação entre o que herdamos e o que adquirimos. Tornamo-nos seres gene-culturais. Não somos apenas natureza nem tampouco somos apenas cultura, educação, cognoscitividade. Por isso, crescer, entre nós, é uma experiência atravessada pela biologia, pela psicologia, pela cultura, pela História, pela educação, pela política, pela estética, pela ética (FREIRE, 1997, p.84, grifo nosso).
}

A cultura, a sociedade e a história tecem o cenário, a paisagem, o território, o espaço, o lugar e o ambiente em que vivemos individual e coletivamente, em que aprendemos a ser o que somos, 'seres gene-culturais'. O material cultural que compõe o conteúdo do que aprendemos bem como os distintos e diversos modos como fazemos e intervimos em nosso crescimento, como nos programamos para aprender o que fomos, somos e podemos ser e como nos inscrevemos no mundo e em nossa história, encontram-se na existência que produzimos.

Um achado extremamente significativo da ordem geral do discurso sobre a aprendizagem, em que Freire se situa e de que se apropria para dizer o que diz, é o enunciado de que a aprendizagem é uma característica inerente ao modo de existência do ser humano, codificado na assertiva de que somos "programados para aprender", de que somos "permanentemente inscritos num processo de aprender e buscar" ou, ainda, de que somos "seres gene-culturais".

Periódico Horizontes - USF - Itatiba, SP - Brasil - e020056 
Certamente, o significado dessas afirmativas assinala o reconhecimento freireano de que o estar sendo no mundo de homens e de mulheres foi e é uma construção social e histórica de que somos seres forjados, produzidos, não determinados naturalmente e em constante processo existencial de aprendizagem. Em outras palavras, fomos o que fomos e somos o que somos porque aprendemos a ser precisamente assim, porque fazemos assim.

Assim, em função do enunciado da aprendizagem como uma atividade inerente à dinâmica da existência humana, Freire entende que o que fomos, o que estamos sendo e o que poderemos ser não se caracterizam como uma espécie de destino, de sina, de herança natural ou coisa do gênero, mas como uma possibilidade assumida, que varia de acordo com o lugar, o tempo, a circunstância e os complexos socioculturais particulares em que vivemos e existimos.

\section{Referências}

ALCANTARA, M. A. M.; CARLOS, E. J. Análise arqueológica do discurso: uma alternativa de investigação na educação de jovens e adultos (EJA). Interseç̧ões: Revista de Estudos sobre Práticas Discursivas e Textuais. Jundiaí/SP, v.3, n.5, p.59-73, nov. 2013. Disponível em: http://www.anchieta.br/unianchieta/revistas/interseccoes/pdf/Interseccoes_Ano_6_Numero_ 3.pdf. Acesso em: 20 dez. 2019.

CARLOS, E. J. Achados sobre a noção arqueológica do discurso em Foucault. Revista Dialectus. a.4, n.11. p.176-191, ago.-dez. 2017. DOI: https://doi.org./10.30611/2017n11id31008. Disponível em: http://www.periodicos.ufc.br/dialectus/article/view/31008. Acesso em: 20 dez. 2019.

CARLOS, E. J. Escavações discursivas sobre a imagem visual em ação cultural para a liberdade. Revista Brasileira de Educação de Jovens e Adultos, v.6, p.9-25, ahead of print, 2018. Disponível em: http://www.revistas.uneb.br/index.php/educajovenseadultos/article/view/5692. Acesso em: 30. ago. 2019.

FOUCAULT, M. A arqueologia do saber. Trad. Luiz Felipe Baeta Neves. 7. ed. Rio de Janeiro: Forense Universitária, 2008.

FREIRE, P. Professora sim, tia não: cartas a quem ousa ensinar. São Paulo: Editora Olho d'Água, 1997.

Recebido em março 2020.

Aprovado em novembro 2020. 
